\title{
HEAT SHOCK EFFECT IN BREAKING PHYSICAL DORMANCY IN SEEDS OF LUPINUS ELEGANS AND L. ROTUNDIFLORUS FROM JalisCO, MeXICO
}

\author{
Erika Robles-Díaz' ${ }^{1}$ Enrique Jurado² ${ }^{2}$ Mario Ruiz-López ${ }^{3}$, Laura Yáñez-Espinosa ${ }^{4}$ \\ AND JOEL FLORES ${ }^{1,5}$ \\ 'División de Ciencias Ambientales, Instituto Potosino de Investigación Científica y Tecnológica, A.C., \\ San Luis Potosí, San Luis Potosí, Mexico \\ ${ }^{2}$ Facultad de Ciencias Forestales, Universidad Autónoma de Nuevo León, Linares, Nuevo León, Mexico \\ ${ }^{3}$ Laboratorio de Biotecnología, Departamento de Botánica y Zoología, Universidad de Guadalajara, \\ Guadalajara, Jalisco, Mexico \\ ${ }^{4}$ Instituto de Investigación de Zonas Desérticas. Facultad de Ingeniería. Universidad Autónoma de San Luis Potosí, \\ San Luis Potosí, San Luis Potosí, Mexico \\ ${ }^{5}$ Corresponding author: joel@ipicyt.edu.mx
}

\begin{abstract}
Most wild Lupinus spp. (Fabaceae) grow in pine and pine-oak forests with natural and induced fires. Their seeds have physical dormancy, which can be broken in response to appropriate environmental signals, such as high temperatures, humidity, and fire. We applied heat treatments to break seed dormancy of L. elegans and L. rotundiflorus from the State of Jalisco, Mexico, with different storage times $(0,1$, and $2 \mathrm{yr}$ for L. elegans and $0,1,2,3$, and $4 \mathrm{yr}$ for L. rotundiflorus). One set of seeds were immersed in boiling water for 5,10 , and $15 \mathrm{~s}$, another set were incubated in wet or dry sand at $100{ }^{\circ} \mathrm{C}, 120^{\circ} \mathrm{C}$, and $150{ }^{\circ} \mathrm{C}$ during $60 \mathrm{~min}$ and $90 \mathrm{~min}$. Germination trials were set at $25^{\circ} \mathrm{C}$ with $12 \mathrm{~h}$ of irradiance per day. For both species, no germination resulted after incubation at 120 and $150{ }^{\circ} \mathrm{C}$. For L. rotundiflorus, germination was higher for seeds incubated in wet sand for 60 min than for those incubated for $90 \mathrm{~min}$. Fresh seeds of $L$. rotundiflorus showed higher germination than stored seeds across treatments. After scarification with boiling water, fresh seeds of L. elegans, germinated more than those stored for 1 and 2 year, whereas incubation in wet and dry sand resulted in higher germination for 1 and 2 year old seeds than for fresh seeds. Our results may be useful for further studies to understand and predict ecological plant responses in Mexican forests.
\end{abstract}

Key words: boiling water, dry sand, seed germination, wet sand.

Resumen: La mayoría de las especies silvestres de Lupinus (Fabaceae) crecen en bosques de pino y pino-encino, en donde se presentan incendios naturales e inducidos. Sus semillas tienen latencia física, la cual puede ser rota en respuesta a señales ambientales como altas temperaturas, humedad y fuego. En esta investigación, se aplicaron tratamientos de calor para romper la latencia de semillas de L. elegans y L. rotundiflorus del estado de Jalisco, México, con diferentes tiempos de almacenamiento ( 0,1 y 2 años para L. elegans y 0, 1, 2, 3 y 4 años para $L$. rotundiflorus). Un grupo de semillas fue sumergido en agua hirviendo por 5,10 y 15 segundos, otro grupo fue incubado en arena húmeda o seca a 100,120 y $150{ }^{\circ} \mathrm{C}$ durante 60 y 90 minutos. Las semillas se pusieron a germinar a $25{ }^{\circ} \mathrm{C}$ con fotoperíodo de 12 horas. Para ambas especies, no hubo germinación en semillas incubadas a 120 y 150 ${ }^{\circ} \mathrm{C}$. Para L. rotundiflorus, la germinación fue más alta en semillas incubadas en arena húmeda por 60 minutos que por 90 minutos. Las semillas frescas de L. rotundiflorus mostraron mayor germinación que las almacenadas, en los distintos tratamientos. Después de la escarificación con agua hirviendo, las semillas frescas de L. elegans germinaron más que las almacenadas por 1 y 2 años, mientras que para las semillas almacenadas por 1 y 2 años la incubación en arena húmeda y seca resultó en mayor germinación que para las semillas frescas. Estos resultados podrían ser útiles para entender y predecir respuestas ecológicas de las plantas en bosques mexicanos.

Palabras clave: agua hirviendo, arena húmeda, arena seca, germinación.

$\mathbf{S}^{\mathrm{cos}}$ eed dormancy is a very common adaptive plant strategy in unpredictable and harsh environments (Jurado and Moles, 2003; Jurado and Flores, 2005). Seeds with physical dormancy (PY) have water-impermeable seed or fruit coat, and are unable to imbibe water when placed in a moist envi- ronment (Baskin and Baskin, 2000; Venier et al., 2012). Impermeability of seed or fruit coat is caused by one or more water impermeable palisade cell layers that form a physical barrier for water entry (Baskin and Baskin, 1998; Baskin et al., 2000). PY as a seed trait has been documented for $17 \mathrm{fa}-$ 
milies of angiosperms, like Cistaceae, Convolvulaceae, Fabaceae, Malvaceae, and Rhamnaceae (Baskin and Baskin, 1998; Baskin et al., 2000; Baskin, 2003; Gama-Arachchige et al., 2010; Karaki et al., 2012).

High temperatures have been suggested to break PY (Baskin and Baskin, 2000; Pérez-Sánchez et al., 2011). Temperature mediates natural breakdown of water impermeable seed layers in two main ways: (1) climatic, through the heating effect of solar radiation on the surface layers of dry soils, coupled with night-time cooling, resulting in a combination of exposure to high temperatures and wide temperature fluctuations, and (2) fire-related through the brief but intense heating on the surface layers of soil caused by fires (Probert, 2000). Several genera of the Fabaceae, like Lupinus, grow in pine and pine-oak forests with natural and induced fires (Espinoza-Martínez et al., 2008; Martínez et al., 2008; Martínez-Hernández and Rodríguez-Trejo, 2008; Zuloaga-Aguilar et al., 2010, 2011). Lupinus seeds have been found to have PY (Burns, 1959; Quinlivan, 1968; Dehgan et al., 2003; Acosta-Percástegui and Rodríguez-Trejo, 2005; Hernández et al., 2008; Martínez et al., 2008; Bolin, 2009; Aldrete-Chávez et al., 2010; Zuloaga-Aguilar et al., 2010; 2011; Elliot et al., 2011), and high temperatures have been suggested to break seed dormancy in several species as L. varius (Quinlivan, 1968) and L. exaltatus (ZuloagaAguilar et al., 2010; 2011), but not in L. texensis (Davis et al., 1991), or L. leptophyllus (Aldrete-Chávez et al., 2010). Although, high temperatures can break seed dormancy, they can also affect seed viability either through accelerated "ageing" (Daws et al., 2007), or by the impact of high temperatures on cellular processes (Probert, 2000), but this remains unexplored for Lupinus spp.

Seeds of Lupinus spp. are orthodox (desiccation-tolerant) (Ellis et al., 1987; Garnczarska et al., 2009); thus, ex situ conservation of Lupinus may be achieved through seed storage. The effect that aging through storage and high temperatures might have on breaking seed dormancy of Lupinus spp. deserves exploring.

Lupinus includes 300 to 500 species occurring in the Mediterranean region and America. Usually they are annual or perennial herbs or shrubs. They have palmately compound or rarely simple leaves, and produce spiraled or whorled arrangement of flowers in a raceme (Sousa and Delgado, 1993). In Mexico nearly 100 wild species occur, 15 are native to the state of Jalisco (Ruiz and Sotelo, 2001).

The objective of this study was to evaluate the effect of combined pretreatments of elevated temperature and humidity, in breaking physical dormancy and promote germination of fresh and stored seeds of two Lupinus species ( $L$. elegans H.B.K and L. rotundiflorus M.E.Jones) common to Jalisco, Mexico. We expected that heat may promote germination as a strategy to establish when competition is low, different temperatures represent fire intensities and also accelerate aging processes.

\section{Materials and methods}

Study species and seed collection. Lupinus elegans is a shrubby legume that grows in disturbed areas in pine and pine-oak forests in Central Mexico, from 1,700 to 3,000 m in elevation (Ruiz-Moreno et al., 2000). It is a common ruderal species; it incorporates nitrogen into the soil and has potential for restoration practices (Alvarado-Sosa et al., 2007). In Jalisco it is found in Autlán, Bolaños, Cuautitlán, Gómez Farías, Mezquitic, and Tecolotlán (Ruiz-Moreno et al., 2000; Ruiz-Moreno and Zamora-Natera, 2006).

Lupinus rotundiflorus is found in open slopes growing alongside Acacia spp., shrubs of Leucaena spp., and arborescent Ipomoea spp. It occasionally grows in pine-oak forests from 1,500 to 2,500 $\mathrm{m}$ in elevation, and often occurs in disturbed areas (McVaugh, 1987). In Jalisco it occurs in Mascota, Talpa, and Tapalpa (Ruiz-Moreno and ZamoraNatera, 2006).

The seeds of Lupinus elegans were obtained from "Sierra de Quila" at 1,780 m a.s.l. and those of L. rotundiflorus from "Tapalpa", Jalisco at 2,350 $\mathrm{m}$ a.s.l. The seeds were collected from at least 30 plants per species, and we obtained ca. $50 \mathrm{~g}$ of clean seed per species. We analyzed fresh, and 1 and $2 \mathrm{yr}$ dry stored seeds of L. elegans; and fresh, and 1, 2, 3, and 4 yr dry stored seeds of $L$. rotundiflorus. We considered fresh seeds those collected two months (L. rotundiflorus) and four months (L. elegans) before the beginning of the lab experiment. All aged seeds were stored in paper-bags at room temperature $\left(22^{\circ} \mathrm{C}\right)$.

Anatomical study of physical dormancy (PY). Samples of three seeds were fixed in formalin-ethanol-glacial acetic acid (Ruzin, 1999), and longitudinally sectioned. Samples were mounted on a carbon double-sided adhesive tape on metal pins and coated with sputter gold to analyze the structure of the testa with a scanning electron microscope (Quanta $^{\mathrm{TM}}$ 200, FEI, OR, $20.00 \mathrm{~Kb}$ ).

Breaking dormancy in intact seeds. The following experiments were applied to intact (not mechanically scarified) seeds in an attempt to break PY: (1) seeds dipped in boiling water for 5,10 , and $15 \mathrm{~s}$; (2) seeds heated for 100, 120, and $150{ }^{\circ} \mathrm{C}$ for 60 and $90 \mathrm{~min}$ on wet and dry sand. Treated and control seeds from both experiments were tested for germination at $25{ }^{\circ} \mathrm{C}$ in a $12 / 12 \mathrm{hr}$ light/dark germination chamber (model Lumistell ICP-19d-c/iv) for 30 days. We used a complete random design, with five replicates of 20 seeds for each treatment. Seeds were placed in Petri dishes with water-agar as substrate sealed with parafilm (Parafilm M, Pechiney Plastic Packaging, Chicago, Ill.). Germination percentages in each treatment were compared with those of control (non-scarified seeds incubated) to determine the effectiveness of the dormancy-breaking treatment. Germination was determined with emergence of the radicle. We 
analyzed fresh and 1 and $2 \mathrm{yr}$ dry stored seeds of L. elegans, and fresh and 1,2,3, and $4 \mathrm{yr}$ dry stored seeds of L. rotundiflorus.

Statistical analyses. We conducted a two-way ANOVA for the germination percentage data of each species for each experiment. Data were arcsine transformed to achieve normal distribution.

Storage time (five for Lupinus rotundiflorus and three for $L$. elegans) and pre-treatment were the factors analyzed in the ANOVA for each experiment. Tukey tests were performed to determine the differences in means among treatments. All analyses were performed using JMP version 8.0.

\section{Results}

Anatomical study of physical dormancy $(P Y)$. We provide direct evidence that fresh and stored seeds of the studied species possess PY by describing the basic structure of seed testa that results in a hard seed coat of Lupinus spp. We found in the seed testa longitudinal sections, four layers inwards from the surface: the cuticle, the epidermis, the hypodermis, and the inner parenchyma. The first barrier to imbibition is the waxy cuticle. The next layer is the epidermis, composed of thick-walled macrosclereids with the long axis oriented perpendicularly to the surface, arranged in a compact palisade layer. Under the epidermis a single layer of osteosclereids separated by wide intercellular spaces for$\mathrm{ms}$ the hypodermis, except under the hilum cleft where it is absent. The fourth innermost layer is parenchymatous, with six rows of tangentially collapsed endosperm remnant cells. At the hilum there is one external layer of macrosclereids forming a counter-palisade layer placed above the palisade layer (Figure 1).

Effect of pretreatments on seed germination. For both species a higher germination percentage was observed for seeds pretreated in boiling water than for control seeds and those from the hot wet and dry sand experiment.

Boiling water. There was a significant effect of pretreatments $(F=48.19, \mathrm{df}=3, P<0.001)$ on the germination of Lupinus elegans seeds. Boiling water for 5, 10, and $15 \mathrm{~s}$ resulted in higher germination than control seeds (Table 1). There was also a significant effect of seed age $(F=19.26$, df $=2, P<0.001)$ in that pretreated fresh seeds germinated less $(30 \pm 4.12 \%)$ than pretreated seeds after 1 yr $(57 \pm 6.31 \%)$ or $2 \mathrm{yr}(49.5 \pm 7.09 \%)$ of dry storage. Interaction between pre-treatment and seed age was not significant (Figure 2; $F$ $=1.55, \mathrm{df}=6, P=0.18$ ).

For Lupinus rotundiflorus seeds, there was a significant effect of pretreatments on germination $(F=82.00, \mathrm{df}=3$, $P<0.0001$ ); boiling water for 5,10 , and $15 \mathrm{~s}$ resulted in higher germination than the control seeds (Table 2). There
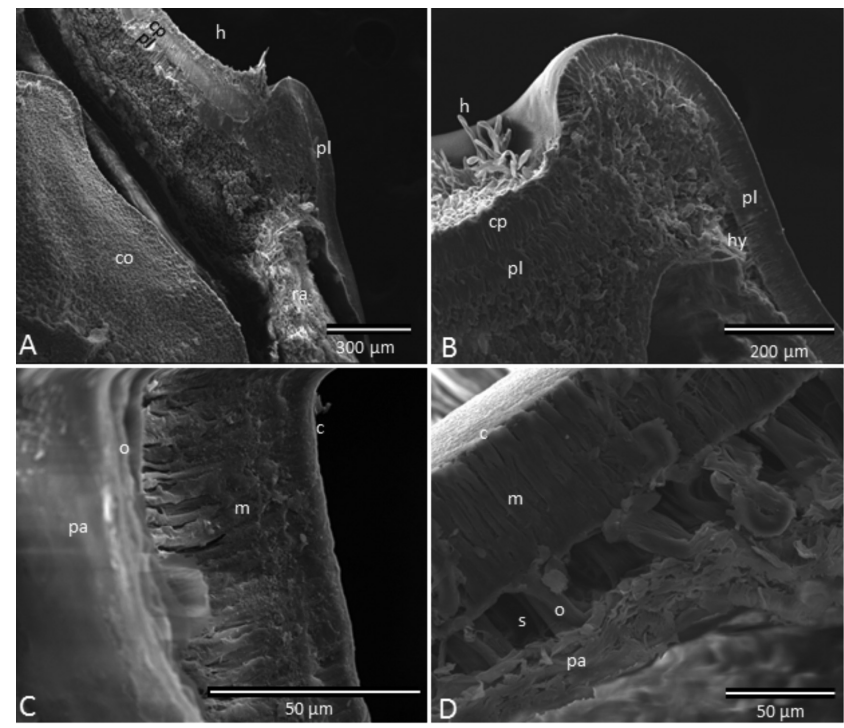

Figure 1. Seed testa longitudinal section SEM micrograph of $\mathrm{Lu}$ pinus. A, C. L. elegans; B, D. L. rotundiflorus. A, B. Hilum region. C. Detail of the cuticle and the palisade layer. D. Detail of the epidermis structure. c, cuticle; co, cotyledon; cp, counter palisade; h, hilum; hy, hypodermis; m, macrosclereids; o, osteosclereids; pa, parenchyma; pl, palisade layer; ra, radicle; s, intercellular spaces.

was also a significant effect of seed age $(F=12.54, \mathrm{df}=4, P$ $<0.0001$ ); on average pretreated fresh seeds showed higher germination $(71.5 \pm 7.65 \%)$ than seeds pretreated after $1 \mathrm{yr}$ $(55 \pm 5.23 \%), 2$ yr $(42.5 \pm 4.83 \%), 3$ yr $(61.5 \pm 4.92 \%)$, or $4 \mathrm{yr}(53.5 \pm 5.91 \%)$ dry storage. Interaction between heat exposure in boiling water and storage time was significant $(F=2.1350, \mathrm{df}=12, P=0.0233)$ in that $2 \mathrm{yr}$ old seeds had similar low germination across pretreatments. Regardless of storage time, seeds germinated more after pre-treatment than control seeds. Fresh seeds showed higher germination than older seeds with pretreatments (Figure 3).

Dry and wet sand. There were differences in germination of Lupinus elegans seeds between pretreatments $(F=10.69$, df $=4, P<0.0001)$. Germination was higher for seeds after wet sand incubation for 60 and $90 \mathrm{~min}$ at $100{ }^{\circ} \mathrm{C}(29 \pm 6.05 \%$ and $32.33 \pm 6.91 \%$, respectively) than for those incubated in

Table 1. Mean final germination $( \pm \mathrm{SE})$ of Lupinus elegans seeds dipped in boiling water for 5, 10 and $15 \mathrm{~s}$. Different letters indicate differences $(P<0.05)$ between means.

\begin{tabular}{lll}
\hline & Pretreatment & $\begin{array}{c}\text { Germination } \\
\text { percentage }\end{array}$ \\
\hline Dipped in boiling water for & $5 \mathrm{sec}$ & $7.33 \pm 3.66^{\mathrm{b}}$ \\
& $10 \mathrm{sec}$ & $59.00 \pm 3.66^{\mathrm{a}}$ \\
& $15 \mathrm{sec}$ & $58.33 \pm 3.66^{\mathrm{a}}$ \\
& & $57.33 \pm 3.66^{\mathrm{a}}$ \\
\hline
\end{tabular}


ERIKA Robles-Díaz ET AL.

Table 2. Mean final germination percentages ( \pm SE) of Lupinus rotundiflorus seeds dipped in boiling water for 5, 10 and $15 \mathrm{~s}$. Different letters indicate differences $(P<0.05)$ between means.

\begin{tabular}{lll}
\hline & Pretreatment & $\begin{array}{c}\text { Germination } \\
\text { percentage }\end{array}$ \\
\hline Dipped in boiling water for & $5 \mathrm{sec}$ & $20.2 \pm 2.46^{\mathrm{b}}$ \\
& $10 \mathrm{sec}$ & $70.2 \pm 2.69^{\mathrm{a}}$ \\
& $15 \mathrm{sec}$ & $69.8 \pm 2.69^{\mathrm{a}}$ \\
& & $67.0 \pm 2.69^{\mathrm{a}}$ \\
\hline
\end{tabular}

dry sand $(13.33 \pm 4.13 \%$ and $22.66 \pm 5.68 \%$, respectively $)$ at the same temperature and control seeds $(7.33 \pm 1.68 \%)$. Seeds exposed to temperatures of 120 and $150{ }^{\circ} \mathrm{C}$ did not germinate. Storage time influenced germination $(F=83.83$, $\mathrm{df}=2, P<0.0001)$, in that the highest germination was obtained for seeds stored for $1 \mathrm{yr}(42 \pm 3.76 \%)$, followed by seeds stored for $2 \mathrm{yr}(17.2 \pm 3.48 \%)$ and fresh seeds $(3.6 \pm$ $0.98 \%)$. The interaction between pretreatment and storage time was significant $(F=5.38, \mathrm{df}=8, P<0.0001)$, in that 1 yr old seeds had higher germination than fresh seeds, and 2 yr old seeds after wet and dry sand incubation (Figure 4).

For Lupinus rotundiflorus, seeds exposed to temperatures of 120 , and $150{ }^{\circ} \mathrm{C}$ did not germinate. Wet sand incubation

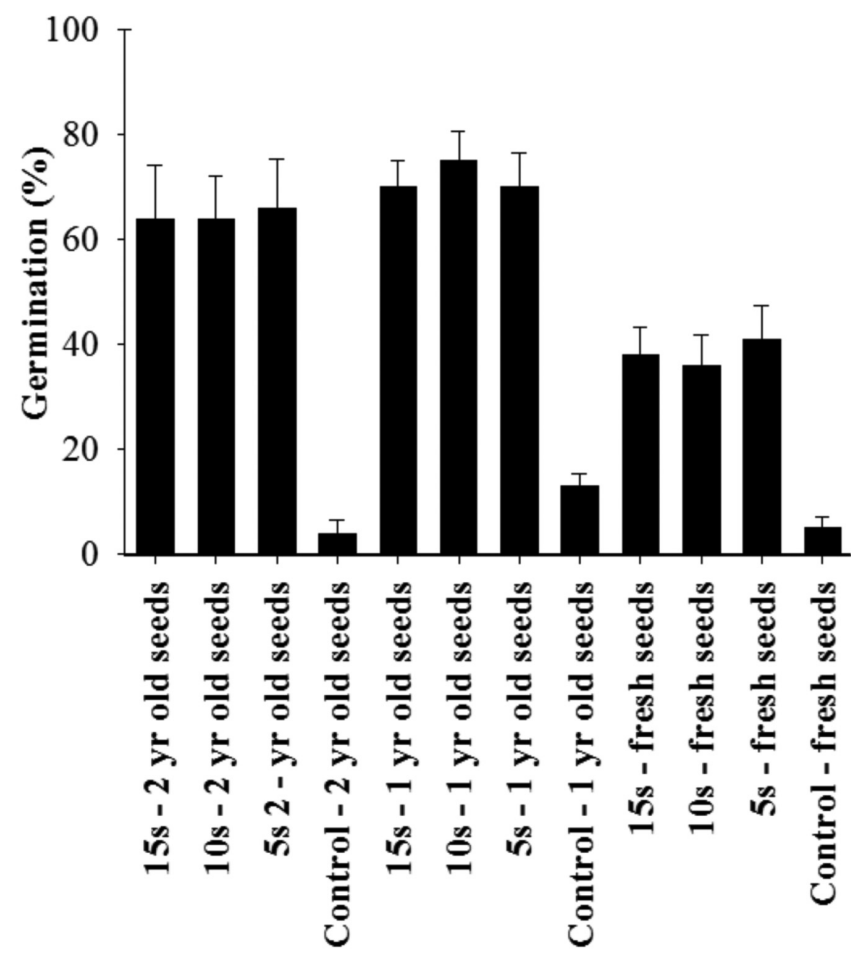

Figure 2. Mean final germination ( \pm SE) of Lupinus elegans seeds of different aging (fresh, 1 and 2 yr) after dipped in boiling water for 5,10 and $15 \mathrm{~s}$. Interaction between boiling and seed age was not significant $(P=0.18)$.

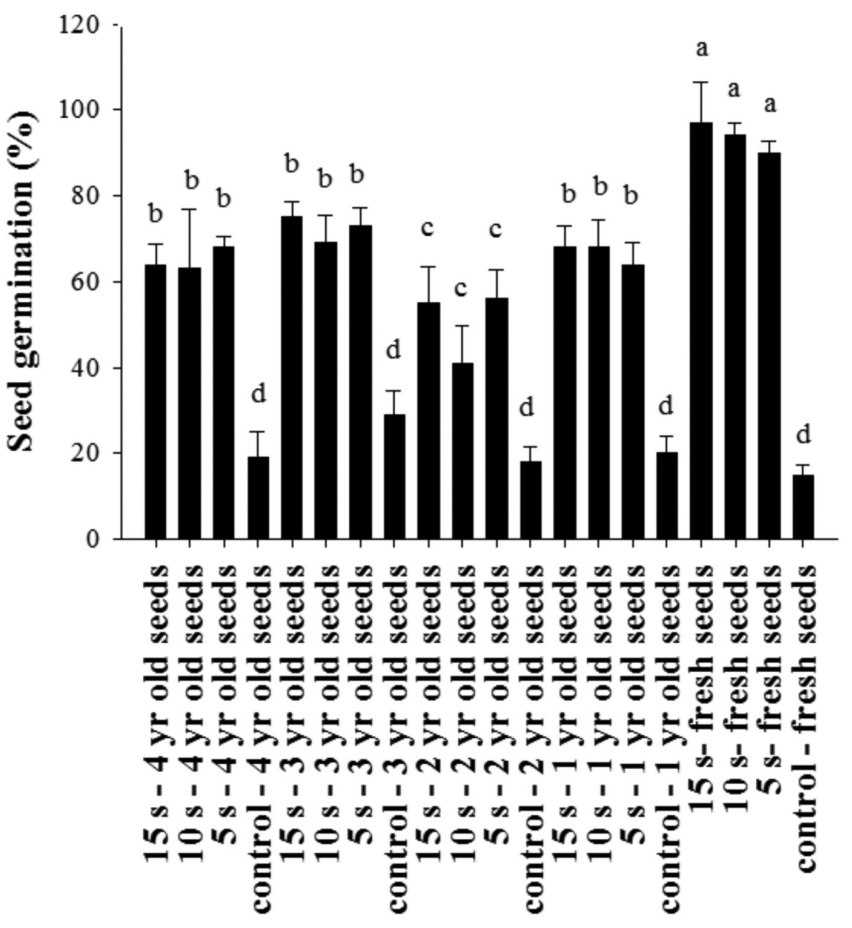

Figure 3. Mean final germination $( \pm \mathrm{SE})$ of Lupinus rotundiflorus seeds of different seed aging (fresh, 1, 2, 3, and $4 \mathrm{yr}$ ) after dipped in boiling water for 5, 10 and $15 \mathrm{~s}$. Different letters indicate differences $(P<0.05)$ between means for the interaction of boiling $\times$ seed age.

for $60 \mathrm{~min}$ at $100{ }^{\circ} \mathrm{C}$ resulted in high germination $(55.8 \pm$ $4.48 \%)$ as well as dry sand incubation for $60 \mathrm{~min}(60.6 \pm$ $4.47 \%)$, and $90 \mathrm{~min}(54 \pm 4.58 \%)$ compared to seeds incubated in moist sand for $90 \mathrm{~min}(32.4 \pm 5.43 \%)$ and control seeds $(20.2 \pm 2.07 \%, F=50.248, \mathrm{df}=4, P<0.0001)$. Storage time also affected germination, pretreated fresh seeds had higher germination $(73.4 \pm 6.28 \%)$ than pretreated seeds after 1 yr $(38.6 \pm 4.05 \%), 2$ yr $(27.6 \pm 3.04 \%), 3 \mathrm{yr}(45.8 \pm$ $4.16 \%)$, or $4 \mathrm{yr}(37.6 \pm 3.58 \%)$ of dry storage $(F=49.870$, $\mathrm{df}=4, P<0.0001)$. The interaction between storage time and pretreatment was significant $(F=4.86, \mathrm{df}=16, P<$ 0.0001 ), in that pretreated fresh seeds germinated more (at least $81 \%$ ) than fresh untreated seeds $(15 \pm 2 \%)$, and control and pretreated stored seeds (Table 3 ).

\section{Discussion}

Seeds of the studied species were found to have structures that provide PY as for other species of Fabaceae with PY (de Souza and Marcos-Filho, 2001). Heat shock caused by high temperatures influenced the breaking of seed dormancy of studied Lupinus species. In general, the pretreatment that resulted in higher germination was boiling water. This result is similar to that obtained for L. varius by Quinlivan (1968) and Karaguzel et al. (2004), as well as for L. lepidus by Elliott 


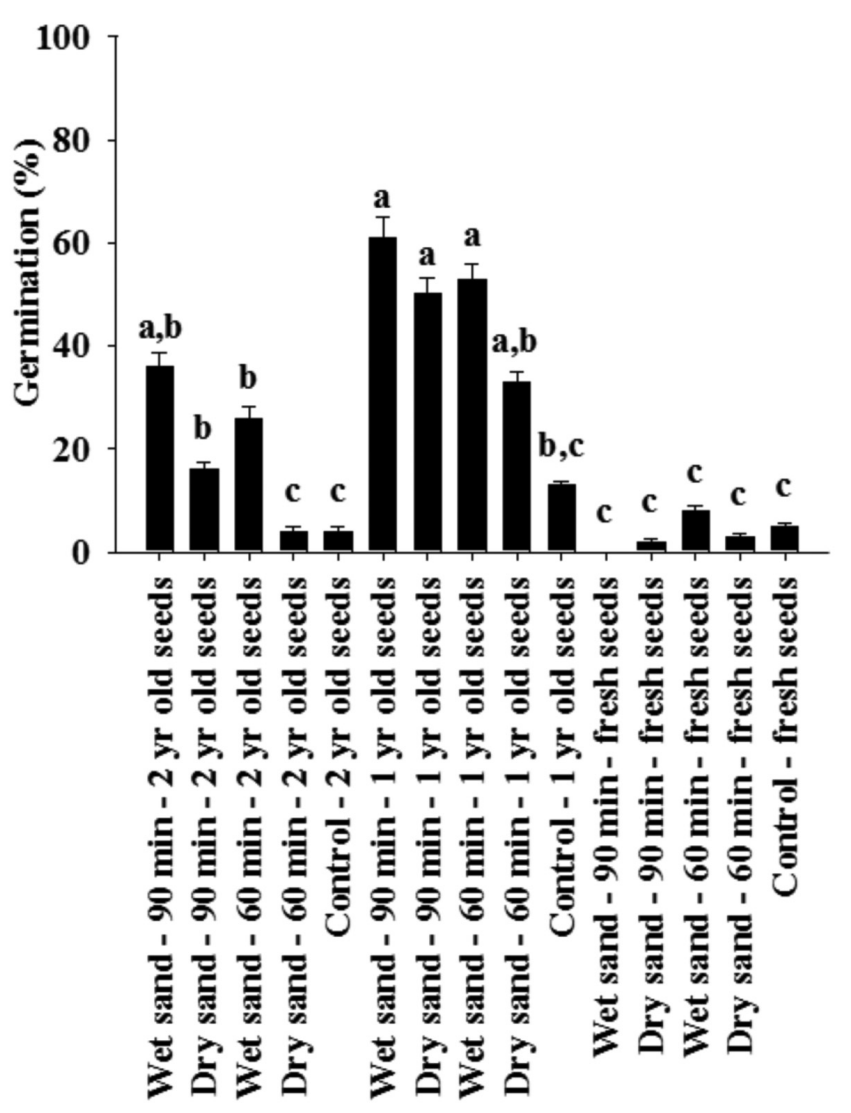

Figure 4. Mean final germination $( \pm \mathrm{SE})$ of Lupinus elegans seeds of different aging (fresh, 1 and $2 \mathrm{yr}$ ) after heated for $100{ }^{\circ} \mathrm{C}$ for 60 and 90 minutes on wet and dry sand. Different letters indicate differences $(P<0.05)$ between means for the interaction of moist/dry heat $\times$ seed age.

et al. (2011). However, it differs from results obtained by Bolin (2009) for L. perennis. For L. polyphyllus almost no germination was obtained after hot water exposure followed by $20{ }^{\circ} \mathrm{C}$ incubation, but $60 \%$ germination was obtained after chilling at $5{ }^{\circ} \mathrm{C}$ for six weeks to simulate winter followed by alternating diurnal temperatures of $15^{\circ} \mathrm{C} / 7^{\circ} \mathrm{C}$ approximating spring conditions (Elliot et al., 2011). This variation implies specific requirements among the species of Lupinus to break dormancy. Because L. elegans and $L$. rotundiflorus grow in high altitudes, the effect of chilling in breaking physical dormancy needs to be tested.

Pretreatment of wet or dry sand produced low germination percentages for Lupinus elegans $(<40 \%$ in wet sand and $<20 \%$ dry sand), and high germination for L. rotundiflorus (>70\% in wet sand and $>50 \%$ dry sand). This implies that species germination responses were not necessarily related to their phylogeny, but perhaps to their environment as suggested by Elliot et al. (2011) for three species of Lupinus of Washington, USA. These authors found that L. lepidus and L. albicaulis, species that are restricted to frequently burned prairies, had stronger responses to high pregermination tem-
Table 3. Mean final germination percentages ( \pm SE) of Lupinus rotundiflorus seeds heated for $100{ }^{\circ} \mathrm{C}$ for 60 and 90 minutes on wet and dry sand. Different letters indicate differences $(P<0.05)$ between means for the interaction of moist/dry heat $\times$ seed age.

\begin{tabular}{|c|c|}
\hline Pretreatment & Germination (\%) \\
\hline Wet sand - $90 \mathrm{~min}-4 \mathrm{yr}$ old seeds & $19 \pm 1.5^{d}$ \\
\hline Dry sand - $90 \mathrm{~min}-4 \mathrm{yr}$ old seeds & $48 \pm 2.3^{b}$ \\
\hline Wet sand - $60 \mathrm{~min}-4 \mathrm{yr}$ old seeds & $49 \pm 2.1^{b}$ \\
\hline Dry sand - $60 \mathrm{~min}-4 \mathrm{yr}$ old seeds & $53 \pm 2.6^{b}$ \\
\hline Control - 4 yr old seeds & $19 \pm 1.6^{d}$ \\
\hline Wet sand - 90 min - 3 yr old seeds & $28 \pm 2.0^{c, d}$ \\
\hline Dry sand - $90 \mathrm{~min}-3 \mathrm{yr}$ old seeds & $58 \pm 3.0^{b}$ \\
\hline Wet sand - $60 \mathrm{~min}-3 \mathrm{yr}$ old seeds & $53 \pm 2.7^{b}$ \\
\hline Dry sand - $60 \mathrm{~min}-3 \mathrm{yr}$ old seeds & $61 \pm 3.1^{b}$ \\
\hline Control - 3 yr old seeds & $29 \pm 1.6^{c}$ \\
\hline Wet sand - 90 min - 2 yr old seeds & $14 \pm 1.0^{d}$ \\
\hline Dry sand - $90 \mathrm{~min}-2 \mathrm{yr}$ old seeds & $30 \pm 2.6^{c}$ \\
\hline Wet sand - $60 \mathrm{~min}-2 \mathrm{yr}$ old seeds & $41 \pm 2.2^{c}$ \\
\hline Dry sand - $60 \mathrm{~min}-2 \mathrm{yr}$ old seeds & $35 \pm 3.0^{c}$ \\
\hline Control - 2 yr old seeds & $18 \pm 1.9^{d}$ \\
\hline Wet sand - 90 min - 1 yr old seeds & $20 \pm 1.5^{d}$ \\
\hline Dry sand - $90 \mathrm{~min}-1 \mathrm{yr}$ old seeds & $43 \pm 2.5^{c}$ \\
\hline Wet sand - $60 \mathrm{~min}-1 \mathrm{yr}$ old seeds & $47 \pm 2.2^{b, c}$ \\
\hline Dry sand - $60 \mathrm{~min}-1 \mathrm{yr}$ old seeds & $63 \pm 3.5^{a, b}$ \\
\hline Control - 1 yr old seeds & $20 \pm 2.0^{d}$ \\
\hline Wet sand - 90 min - fresh seeds & $81 \pm 4.7^{\mathrm{a}}$ \\
\hline Dry sand - 90 min - fresh seeds & $90 \pm 5.0^{a}$ \\
\hline Wet sand - 60 min - fresh seeds & $90 \pm 4.0^{\mathrm{a}}$ \\
\hline Dry sand - 60 min - fresh seeds & $91 \pm 5.5^{\text {a }}$ \\
\hline Control - fresh seeds & $15 \pm 2.0^{d}$ \\
\hline
\end{tabular}

perature regimes. In contrast, L. polyphyllus, with a broader distribution showed less response to high pregermination temperatures, and minor response to fluctuating spring temperature regimes.

Temperatures above $100{ }^{\circ} \mathrm{C}$ adversely affected germination of our species, suggesting that they are not adapted to germinate after very intense fires. Loss of viability after heat was probably due to embryo damage, as reported by Keeley et al. (1985) for Marah macrocarpus, Paeonia californica, Stipa coronata, and Zigadenus fremontii, as well as by Cruz et al. (2003) for Erica australis at $150^{\circ} \mathrm{C}$. For some species in the Fabaceae, damage of seeds inhibiting germination has been found even at relatively low temperatures $\left(>90^{\circ} \mathrm{C}\right)$. Martin et al. (1975) found that temperatures above $90{ }^{\circ} \mathrm{C}$ were lethal for seeds of Cassia, Desmodium, Galactia, and Lespedeza. Stored seeds of Lupinus elegans showed higher germination than fresh seeds, suggesting that physical dormancy is lost with age. Therefore, this species probably has 
the ability to form seed banks in the soil. For L. rotundiflorus however, fresh seeds germinated more after being exposed to wet and dry hot sand, implying that physical dormancy can be easily broken by heat shock in the same year seeds were produced. This also implies that species germination responses are not necessarily related to their phylogeny.

Storage of seeds did not break their dormancy, but high temperatures did. High temperatures helped break seed dormancy, although high temperatures affected seed viability because 90 min treatments with dry or wet sand showed decreased germination compared with 60 min treatments for Lupinus rotundiflorus. Rapid 'accelerated' ageing by the impact of high temperatures might damage cellular structures (Daws et al., 2007).

As it has been suggested for other species growing in harsh environments (Jurado and Flores, 2005), the hard and impermeable seed coat found for Lupinus elegans and $L$. rotundiflorus allows the seeds to endure the stressful high temperatures of open sites where these species occur. Our results on effect of heat on breaking seed dormancy is a first approach to investigate the regeneration biology of species in pine and pine-oak forests in Central Mexico and may be useful for further studies to understand and predict ecological plant responses in Mexican forests.

\section{Acknowledgements}

This study was supported by Consejo Nacional de Ciencia y Tecnología-Fondos Sectoriales-Secretaría de Medio Ambiente y Recursos Naturales (2006-1-23818). Robles-Díaz, E. was supported by a grant (090388) from Consejo Nacional de Ciencia y Tecnología during her master degree studies at Instituto Potosino de Investigación Científica y Tecnológica. Araceli Patrón (División de Biología Molecular-IPICYT) provided assistance with SEM. We thank two anonymous reviewers for contributing to improve the manuscript.

\section{Literature cited}

Acosta-Percástegui J. and Rodríguez-Trejo D.A. 2005. Factors affecting germination and pregerminative treatments of Lupinus montanus seeds. Interciencia 30:576-579.

Aldrete-Chávez A., Rodríguez-Trejo D.A., Espinosa-Hernández V., Ojeda-Trejo E., and de la Cruz-Landero N. 2010. Effects of different scarification treatments on the germination of Lupinus leptophyllus seeds. International Journal of Botany 6:64-68.

Alvarado-Sosa P., Blanco-García A. and Lindig-Cisneros R. 2007. Test of alternative propagation conditions for Lupinus elegans Kunth plants, and effects on field survival. Revista Fitotecnia Mexicana 30:201-204.

Baskin C.C. 2003. Breaking physical dormancy in seeds - focussing on the lens. New Phytologist 158:229-232.

Baskin C.C. and Baskin J.M. 1998. Seeds: Ecology, Biogeography and Evolution of Dormancy and Germination. Academic Press, San Diego.
Baskin J.M. and Baskin C.C. 2000. Evolutionary considerations of claims of physical dormancy-break by microbial action and abrasion by soil particles. Seed Science Research 10:409-413.

Baskin J.M., Baskin C.C. and Li X. 2000. Taxonomy, anatomy and evolution of physical dormancy in seeds. Plant Species Biology 15:139-152.

Bolin J.F. 2009. Heat shock germination responses of three Eastern North American temperate species. Castanea 74:160-167.

Burns R.E. 1959. Effect of acid scarification on lupine seed impermeability. Plant Physiology 34: 107-108.

Cruz A., Pérez B., Velasco A. and Moreno J.M. 2003. Variability in seed germination at the interpopulation, intrapopulation and intraindividual levels of the shrub Erica australis in response to fire-related cues. Plant Ecology 169:93-103.

Davis T.D., George S.W., Upadhyaya A. and Parsons J. 1991. Improvement of seedling emergence of Lupinus texensis Hook. following seed scarification treatments. Journal of Environmental Horticulture 9:17-21.

Daws M.I., Kabadajic A., Manger K. and Kranner I. 2007. Extreme thermo-tolerance in seeds of desert succulents is related to maximum annual temperature. South African Journal of Botany 73:262-265.

Dehgan B., Norcini J.G., Kabat S.M. and Pérez H.E. 2003. Effect of seed scarification and gibberellic acid treatment on seedling emergence of Sky-Blue Lupine (Lupinus diffusus). Journal of Environmental Horticulture 21:64-67.

de Souza, F.H.D. and Marcos-Filho J. 2001. The seed coat as a modulator of seed environment relationships in Fabaceae. Revista Brasileira de Botanica 24:365-375.

Elliott C.W., Fischer D.G. and LeRoy C.J. 2011. Germination of three native Lupinus species in response to temperature. Northwest Science 85:403-410.

Ellis R.H., Hong T.D. and Roberts E.H. 1987. The development of desiccation-tolerance and maximum seed quality during seed maturation in six grain legumes. Annals of Botany 59:23-29.

Espinoza-Martínez L.A., Rodríguez-Trejo D.A. and Zamudio-Sánchez F.J. 2008. Sinecología del sotobosque de Pinus hartwegii dos y tres años después de quemas prescritas. Agrociencia $\mathbf{4 2}$ : 717-730.

Gama-Arachchige N.S., Baskin J.M., Geneve R.L. and Baskin C.C. 2010. Identification and characterization of the water gap in physically dormant seeds of Geraniaceae, with special reference to Geranium carolinianum. Annals of Botany 105:977-990.

Garnczarska M., Bednarski W. and Jancelewicz M. 2009. Ability of lupine seeds to germinate and to tolerate desiccation as related to changes in free radical level and antioxidants in freshly harvested seeds. Plant Physiology and Biochemistry 47:56-62.

Hernández-Ferretiz E., Rivera-Meléndez R.K., Ramos-Herrera O. J., Salinas-Pérez F.C., Rodríguez-Monroy M. and BermúdezTorres K. 2008. Effect of scarification treatments on germination of Lupinus montanus HBK Seeds. In: Palta J.A. and Berger J.B. Eds. 2008. Lupinus for Health and Wealth. Proceedings of the 12th International Lupin Conference, pp. 405-409, Fremantle, Western Australia, International Lupin Association, Canterbury.

Jurado E. and Flores J. 2005. Is seed dormancy under environmental control or bound to plant traits? Journal of Vegetation Science 16:559-564.

Jurado E. and Moles A. 2003. Germination deferment strategies. In: Nicolás G., Bradford K.J., Côme D. and Pritchard H.W. Eds. 
The Biology of Seeds: Recent Research Advances, pp. 381-388, CABI Publishing, Wallingford.

Karaguzel O., Cakmakci S., Ortacesme V. and Aydinoglu B. 2004. Influence of seed coat treatments on germination and early seedling growth of Lupinus varius L. Pakistan Journal of Botany 36:65-74.

Karaki T., Watanabe Y., Kondo T. and Koike T. 2012. Strophiole of seeds of the black locust acts as a water gap. Plant Species Biology 27:226-232.

Keeley J.E., Morton B.A., Pedrosa A. and Trotter P. 1985. Role of allelopathy, heat and charred wood in the germination of chaparral herbs and suffrutescents. Journal of Ecology 73:445-458.

Martin R.E., Miller R.L. and Cushwa C.T. 1975. Germination response of legume seeds subjected to moist and dry heat. Ecology 56:1441-1445.

Martínez J.M., Rodríguez-Trejo D.A., Guizar-Nolazco E. and Bonilla-Beas R. 2008. Escarificación artificial y natural de la semilla de Lupinus bilineatus Benth. Revista Chapingo Serie Ciencias Forestales y del Ambiente 14:73-79.

Martínez-Hernández O.C. and Rodríguez-Trejo D.A. 2008. Species diversity after prescribed burns at different intensities and seasons in a high altitude Pinus hartwegii forest. Interciencia 33:337-344.

McVaugh R. 1987. Flora Novo-Galiciana: A descriptive account of the vascular plants of Western Mexico, Vol. 5 Leguminosae. The University of Michigan Press, Ann Arbor.

Pérez-Sánchez R.M., Jurado E., Chapa-Vargas L. and Flores J. 2011. Seed germination of Southern Chihuahuan Desert plants in response to elevated temperatures. Journal of Arid Environments 75:978-980.

Probert R.J. 2000. The role of temperature in the regulation of seed dormancy and germination. In: Fenner M. Ed. Seeds: The Ecology of Regeneration in Plant Communities, $2^{\text {nd }}$ edition, 261292, CABI Publishing, Wallingford.

Quinlivan B.J. 1968. The softening of hard seeds of sand-plain
Lupin (Lupinus varius L.). Australian Journal of Agricultural Research 19:507-515.

Ruiz L.M. and Sotelo A. 2001. Chemical composition, nutritive value, and toxicology evaluation of Mexican wild lupins. Journal of Agricultural and Food Chemistry 49:5336-5339.

Ruiz-Moreno J.J. and Zamora-Natera J.F. 2006. Distribución de algunos lupinos silvestre en la zona occidente de México. In: Bañuelos P.J., Ruiz L.M., Soltero Q.R. and Castañeda V.H. Eds. Lupinos del Occidente de México: Estudios Biológico, Bioquímico y Toxicológico, pp. 33-52, Universidad de Guadalajara, Guadalajara.

Ruiz-Moreno J.J., Ruiz-Lopez M.M., Zamora-Natera J.F. 2000. The genus Lupinus: Taxonomy and distribution in Jalisco, Mexico. In: van Santen E., Wink M., Weissmann S. and Römer P. Eds. Lupin, an ancient crop for the new millennium: Proceedings of the 9th International Lupin Conference, pp. 297300, Müritz.

Ruzin S.E. 1999. Plant Microtechnique and Microscopy. Oxford University Press, New York.

Sousa M. and Delgado A. 1993. Mexican Leguminosae: Phytogeography, endemism and origins. In: Ramamoorthy T.P., Bye R., Lot A. and Fa J. Eds. Biological Diversity of Mexico: Origins and Distribution, pp. 459-511, Oxford University Press, Oxford.

Venier P., Funes G. and Carrizo-García C. 2012. Physical dormancy and histological features of seeds of five Acacia species (Fabaceae) from xerophytic forests in central Argentina. Flora 207:39-46.

Zuloaga-Aguilar S., Briones O. and Orozco-Segovia A. 2010. Effect of heat shock on germination of 23 plant species in pineoak and montane cloud forests in western Mexico. International Journal of Wildland Fire 19:759-773.

Zuloaga-Aguilar S., Briones O. and Orozco-Segovia A. 2011. Seed germination of montane forest species in response to ash, smoke and heat shock in Mexico. Acta Oecologica 37:256-262.

Received: January 4th, 2013

Accepted: May 9th, 2013 